\title{
Whose Hometown? Reception of Bruce Springsteen as an Index of Australian National Identities
}

\author{
Brad Warren and Patrick West \\ Deakin University
}

\begin{abstract}
Focusing on the cultural landscape of the mid-1980s, this paper explores the Australian experience of Bruce Springsteen. Australian author Peter Carey's short story collection, The Fat Man in History, anticipates two phases of Australia's relationship to the United States, phases expressed by responses to Springsteen's Born in the U.S.A. (1984) and the 1986 blockbuster Crocodile Dundee. Springsteen's album was received by an Australian audience who wanted to be like Americans; Crocodile Dundee, on the other hand, provided a representation of what Australians thought Americans wanted Australians to be. This paper argues that the first phase was driven by emergent technologies, in particular the Walkman, which allowed for personal and private listening practices. However, technological changes in the 1990s facilitated a more marked shift in listening space towards individualization, a change reflected in Springsteen's lyrics.
\end{abstract}

"The past is a foreign country: they do things differently there." - L.P. Hartley ${ }^{1}$

Looking back on 1984, it proves difficult to fully appreciate the immensity of Born in the U.S.A. for Australian music fans. The album bore distinctly American rock music, indicated by the American flag on the cover of the record, and yet the album spent almost two years near the top of the Australian music charts. Then,

Copyright $@$ Brad Warren and Patrick West, 2014. The authors wish to thank the three, anonymous peer-reviewers for their detailed and insightful comments. Please address correspondence to bradpwarren1@gmail.com and patrick.west@deakin.edu.au

${ }^{1}$ L.P. Hartley, The Go-Between (New York: New York Review of Book, 2002 [1953]), 17.

BOSS: The Biannual Online-Journal of Springsteen Studies 1.1 (2014)

http://boss.mcgill.ca/ 
in 1985 Bruce Springsteen performed eight sell-out stadium shows in our hometown. Springsteen still sells out stadiums in Australia, with two highly successful tours over the past twelve months, but the Australian relationship with him and his music has changed. Focusing on the cultural landscape of the mid-1980s, this paper will explore the Australian experience with Springsteen's music, focusing in particular on the fascination with all things American that provided the context for Born in the U.S.A.'s release. In a world before the internet, America was a distant and exotic place that Australia, as a nation, aspired to be like and, accordingly, wanted to emulate. It mattered little that the lyrics to Born in the U.S.A.'s title track did not promote American life. Singing along with the chorus line was more than enough to make Australian listeners feel connected to the United States. Thus, in this paper we concentrate heavily, but not exclusively, on this song.

Springsteen's enormous impact globally makes it difficult to distinguish the different elements of his cultural reception across places and times. Given his celebration and canonization as an icon of American rock, it proves particularly important to explore the nuances of his reception in other contexts, such as Australia, both in the mid-1980s and a decade into the twenty-first century. Attention to the reception of Springsteen's music helps map the differences of perspective on nationhood and identity between North America and the margins of global American hegemony.

Australians' relationship with Springsteen's music does not only have a spatial aspect, but also a temporal dimension. In the decades since 1984, the relationship between the United States and Australia has evolved and the Australian experience of Springsteen's music has matured. In the twenty-first century, this 
experience remains characterized by more personalized responses to popular music, a process facilitated by contemporary technologies. How we listen is as important as what we listen to. In this article, we examine the rise of increasingly individualized listening experiences, traced from the Walkman through to the iPod. Technological and cultural changes exist in symbiotic relation: they mutually constitute political, economic, and social conditions at a global level. Our paper will trace how Australians listened to, and continue to listen to, Springsteen as an index of the changes in the Australian-American cultural relationship.

Throughout this paper, we will draw on our own experiences of growing up in Australia with Springsteen's music, focusing particularly on the 1984 release of Born in the U.S.A. and the Australian tour the following year. We will also draw on the work of Australian writer Peter Carey, in particular his short story collection The Fat Man in History, as well as the 1986 Paul Hogan film Crocodile Dundee, directed by Peter Faiman. These Australian works allow us to unlock the subtleties, shifts, and ironies of Springsteen's reception in this country. This article argues that Carey's text anticipates two phases of Australia's relationship to America in the mid-1980s. These phases are marked by Australians' different responses to Born in the U.S.A. (Phase One) and Crocodile Dundee (Phase Two). Springsteen's album was well received by Australian audiences who, to a large extent, wanted to be, or at the very least wanted to emulate or mirror, Americans. Crocodile Dundee, on the other hand, re-inflected this desire. As a representation by Australians of what Australians thought Americans wanted Australianness to mean, the film constitutes one of the first moments in which Australia, as a nation, engaged

BOSS: The Biannual Online-Journal of Springsteen Studies 1.1 (2014) 
directly with what Americans thought of them. This process would become manifest and manifold in later years with the rise of digital technology, which enabled what we call the "personalization of national imaginaries": every Australian could be American in his or her own way. We further argue that Springsteen's lyrics since Born in the U.S.A. respond to the technological opportunities of selfdefinition opened up by new media. As such, we compare the differences between the specific geographic and cultural signifiers in "Born in the U.S.A." with the more fluid and ambiguous referents to be found in the more recent "We Take Care of Our Own" (2012). ${ }^{2}$

As late as 1988, Peter Carey's The Fat Man in History was still being taught in first-year university English courses in Australia as a text that reflected contemporary Australian-American relations, underscoring its relevance to the time period that encompassed

${ }^{2}$ A note on methodology: The methodological approach adopted by this paper is informed by the respective areas of expertise of its authors. West works in the areas of literary and other text-based critical studies. Specifically, he is interested in how avante garde or surrealist art, the school to which The Fat Man in History belongs, has an established lineage of anticipating developments in mainstream or popular culture. Warren is a sociologist specializing in qualitative method, particularly ethnography and participant observation fieldwork. These areas of expertise underpin this paper's use of personal anecdote on the understanding that the active role played by researcher subjectivity be acknowledged and embraced as a part of the generation of meaning, rather than somehow inhibiting it. As Corrine Glesne and Alan Peshkin write, "Our subjective dispositions may direct us to a variety of different things. This variety reveals the multiple realities of any social phenomenon, which together provide a fuller picture of the people, the times, and the place." (Corrine Glesne and Alan Peshkin, Becoming Qualitative Researchers: An Introduction [White Plains, New York: Longman, 1992], 50). Both of this article's authors grew up in Australia, are passionate Springsteen fans, and were in their mid-to-late teens when Born in the U.S.A. was released. This background facilitates a description of the "foreign country" Hartley refers to through the lenses of personal memories.

BOSS: The Biannual Online-Journal of Springsteen Studies 1.1 (2014) 
Australia's two-year love affair with Born in the U.S.A. ${ }^{3}$ The Australian preoccupation with American culture in the 1980s recurs in four of The Fat Man in History's twelve stories: "American Dreams," "Report on the Shadow Industry," "A Windmill in the West," and the title story, "The Fat Man in History." Set in a small town in Australia, "American Dreams" associates yearnings for modernization with a yearning for America. This linkage provides an apt example of Phase One of the Australian-American relationship. From the outset, the narrator of the story, a young resident representative of the townspeople's collective will, expresses the townspeople's dissatisfaction with their locale and their possessions:

My father says we have treated the town [in Australia] badly in our minds. We have used it, this little valley, as nothing more than a stopping place. Somewhere on the way to somewhere else ... For years we have watched the films at the Roxy and dreamed ... we all have dreams of the big city, of wealth, of modern houses, of big motor cars: American dreams, my father has called them. ${ }^{4}$

As the story progresses, a character named Gleason builds a miniature model of the small Australian town on a bald hill on its outskirts. The narrator's father speculates as to the model's

${ }^{3}$ The University of Melbourne is one such institution. Further, a collection of Carey's work is still on the suggested reading list of the Victorian Year Twelve English syllabus in 2014. It contains three of the four stories from Fat Man discussed in this paper. In 2012, Carey was the only Australian author on the recommended list of short story collections for high school-level instruction; see: http://www.vcaa.vic.edu.au/documents/bulletin/2012/2012febsup3.pdf and http://www.vcaa.vic.edu.au/documents/vce/literature/vce_literature_text_li st.pdf (accessed June 2014)

${ }_{4}^{4}$ Peter Carey, The Fat Man in History, (St. Lucia, Queensland: University of Queensland Press, 1974), 101, 112.

BOSS: The Biannual Online-Journal of Springsteen Studies 1.1 (2014) 
purpose: "He thought Gleason had built the model of our town just for this moment, to let us see the beauty of our own town, to make us proud of ourselves and to stop the American Dreams we were so prone to." ${ }^{5}$ Carey's story serves to criticize the Australian fascination with America through Gleason's seemingly proAustralian project. However, "American Dreams" is also fatalistic about the possible success of the model town project, since it eventually serves to function as nothing more than an attraction to bring American tourists to town. ${ }^{6}$ Traces of our Phase Two can also be found in "American Dreams." The story bears witness to Australians interacting with America, rather than just imagining an idyllic version of it and wishing they were there. When the townspeople are told that the model of the town will bring American tourists, they are at first overjoyed; it seems like a dream come true. So set are they in Phase One, they fantasize about what the Americans will be like. When the American tourists do come, it transpires that the relationship is not quite all it might be:

The Americans would come, [the town minister] said ... And we all began, once more, to dream our American dreams ... Then we all went home and waited for the Americans ... It didn't take long for them to come, although at the time it seemed an eternity ... The Americans arrive every day ... They spend their time being disappointed and I spend my time feeling guilty, that I have somehow let them down by growing older and sadder. ${ }^{7}$

The narrator describes his disappointment at being unable to live up to American expectations, to be the way they would like him to be. This passage, however, illustrates a moment of engagement

${ }^{5}$ Carey, The Fat Man in History, 108.

${ }^{6}$ Carey, The Fat Man in History, 110-11, 13.

${ }^{7}$ Carey, The Fat Man in History, 110-13.

BOSS: The Biannual Online-Journal of Springsteen Studies 1.1 (2014) 
between nations - in the form of actual, fictionalized, interactionrather than merely engagement in characters' imaginations.

Carey's critique of Australians as manqué Americans continues in "Report on the Shadow Industry." In addition to the modernization drive identified above, Carey suggests that a fascination with style over substance constitutes part of Australians' longing for Americanness. While no doubt this is a derogatory claim to make about American culture, the view expressed of Australians is even worse. Not only do they actively seek to follow mindlessly behind Americans, but they lag sorely behind those they aspire to become:

My friend S. went to live in America ten years ago and I still have the letter he wrote me when he first arrived, wherein he describes the shadow factories that were springing up on the west coast ... A strange letter ten years ago but it accurately describes scenes that have since become common in this country [Australia] ... The shadow factories have huge chimneys that reach far into the sky, chimneys which billow forth smoke of different, brilliant colours. It is said by some of my more cynical friends that the smoke has nothing to do with any manufacturing process and is merely a trick, fake evidence that technological miracles are being performed within the factories. ${ }^{8}$

Similar themes can be found in "The Fat Man in History," wherein Americans are described, en masse, as successful and affluent. Yet while Carey's narrator suggests that all Australians long to become Americans, the story again casts these desires in disparaging terms, stating that "most fat men [in Australia] were either Americans, stooges for the Americans, or wealthy supporters of the

\footnotetext{
${ }^{8}$ Carey, The Fat Man in History, 91.
}

BOSS: The Biannual Online-Journal of Springsteen Studies 1.1 (2014) 
Americans."9 The final story in Carey's collection, "A Windmill in the West," takes place in a large American military base in the Australian outback where the land belonging to the base is deemed to be American soil. A lone sentry guards an expanse of the fence surrounding the base, but so similar does the terrain on either side appear that the sentry loses track of which side is which. The story presents a grand metaphor: so much do Australians seek to mimic America that the difference in appearances becomes impossible to discern. Once again, Carey's cynicism towards this state of affairs proves abundantly clear, as the story ends in disaster. ${ }^{10}$

Carey's story collection The Fat Man in History conveys a sense of what the cultural terrain, the "foreign country" of 1984 was like for Australians. It was a world without the internet, without Google, without Skype, where phones were mostly located in homes, fixed firmly to walls, and international call rates were exorbitant. International postage was certainly well established, but delivery turnaround was measured in weeks, if not months. For Australians in this context, America was a distant, utopian land surreal, enticing, and relatively unattainable. This backdrop, Phase One of Australian-American relations, provided a setting ripe with potential for popular reception of Born in the U.S.A. Chart statistics illustrate that Springsteen's album found fertile ground in Australia: the first single from the album, "Dancing in the Dark," entered the Australian Music Charts on May 28, 1984 and remained there for over a year, peaking at number five. The full album arrived on the charts on June 18, peaked at number one (for seven

${ }^{9}$ Carey, The Fat Man in History, 115-16.

${ }^{10}$ Carey, The Fat Man in History, 58, 62, 66

BOSS: The Biannual Online-Journal of Springsteen Studies 1.1 (2014) 
weeks), and remained on the charts for a staggering 97 weeks. ${ }^{11}$ Perhaps the greatest evidence of the Phase One we have described came with the release of the title track as a single: the "Born in the U.S.A." seven-inch came out in January 1985, peaked at number two on the Australian Charts, and remained there for almost half a year. ${ }^{12}$ In late 1986, sales of Springsteen's Live 1975-1985 shattered previous records for albums sold in a single day; the Sydney Morning Herald commented, "Only one American could generate such enthusiasm - Bruce Springsteen." 13

Born in the U.S.A. was not successful by accident, nor was it somehow successful despite the title track. Australians were buying that track on its own merits and screaming it at the top of their lungs, claiming that they were, or at least wished they had been, "born in the U.S.A." As late as 2011, Australians retained a deep association between "Born in the U.S.A." and American identity; a Canberra musician noted that he would not play the song at a Springsteen tribute concert because "it's just ... such an American song that I'm not comfortable with it."14 In 1984, however, Australian listeners were caught up in a vicarious or perhaps voyeuristic version of what Laurent Berlant terms the American National Symbolic, "'an explication of ongoing collective practices' ... [which] helps to account for the multiple, entangled ways in which United States [in this case, Australian] citizens are

11 David Kent, Australian Chart Book 1970 -1992, (St. Ives, N.S.W: Australian Chart Book, 1993), 289.

12 Kent, Australian Chart Book, 289.

13 Paul Sheehan, "The Boss's Record Breaks All Others," Sydney Morning Herald, November 12, 1986, 1.

14 Canberra Times, "Paying Tribute to The Boss," October 31, 2011, 14.

BOSS: The Biannual Online-Journal of Springsteen Studies 1.1 (2014) 
constructed and imagine themselves Americans."15 For Australians, identifying with "Born in the U.S.A." indicated a striving for the modernization that the United States symbolized for Australians at that time.

The authors readily acknowledge that we are treating groups such as American audiences and Australian audiences with broad strokes, perhaps implying inaccurately that either was somehow a homogeneous whole. Such is not the case. Rather, our argument recognizes that the cultural conditions described here were widespread, but certainly not the only ones that existed. For example, in some ways, there was already a real, material dialogue as a dimension of Australian-American relations. Almost 60,000 Australian soldiers served in the Vietnam War, with 521 casualties, and over 3,000 wounded. ${ }^{16}$ Of the survivors and their families, those with discerning ears could easily have moved beyond the chorus line and achieved a different reading altogether of "Born in the U.S.A.," whose narrative tells the story of the homecoming of an American Vietnam War veteran. An anecdote provides evidence of a different possible negotiated engagement: in the course of writing this paper, Warren discussed it in passing with his younger brother, who was ten years old when Born in the U.S.A. was released. He remembers hearing "Born in the U.S.A" but recalls trying to subvert the lyrics, singing the chorus as "born in AUSTRAL-I-A!" Thus, we have three divergent national experiences of "Born in the U.S.A.": that of Australians with dreams of being

15 Cited in Brenda M. Boyle, Masculinity in Vietnam War Narratives: A Critical Study of Fiction, Films and Nonfiction Writings (Jefferson, North Carolina: McFarland and Company, 2009), 7.

16 Australian War Memorial (2013), accessed December 2013,

http://www.awm.gov.au/atwar/vietnam.asp

BOSS: The Biannual Online-Journal of Springsteen Studies 1.1 (2014) 
American (still the prevalent case, we would argue); that of Australians with shared experiences of Vietnam who may relate to the personal realities expressed in the verse narrative; and that of Australians who liked the music but resisted the chorus line. These three stand in for many other possible interpretations, formed on an individual basis. ${ }^{17}$

Yet, there remains more to be said about the way Born in the U.S.A., as a product, was received and consumed. For a great proportion of its audience, the authors included, the album was not a vinyl record but a cassette tape and the method of reception was via headphones plugged into a Walkman. What we listen to is important, but so is how we listen. The Walkman, released in the late 1970s, revolutionized the way the world listened to music, so much so that in 1981 Cliff Richard dedicated an album to it, Wired for Sound. Suddenly, listening to music provided an experience more personal, more private, and at the same time more portable. The following passage from Rey Chow in 1993 now appears quite dated, though it illustrates the immensity of the change:

What we need ... is a history of listening - a history of how listening and how the emotions that are involved in listening change with the apparatuses that make listening possible. Traditionally, listening is, as a rule, public. For a piece of music to be heard-even under the most private

17 Cultural Studies literature provides some inroads into understanding the process through which meaning is made: "[It is] an ongoing process. It does not just end at a pre-ordained point. While producers attempt to encode products with particular meanings and associations, this is not the end of the story ... rather meanings are actively made in consumption, through the use to which people put these products in their everyday lives. "Paul du Gay, Stuart Hall, Linda Janes, Hugh Mackay, and Keith Negus, Doing Cultural Studies: The Story of the Sony Walkman (London: Sage Publications, 1997), 5.

BOSS: The Biannual Online-Journal of Springsteen Studies 1.1 (2014) 
circumstances - a certain public accessibility can always be assumed. Such public accessibility continues even when music becomes portable with the transistor radio and the portable cassette tape player. With the intervention of headphones, on the other hand, listening enters an era of interiorization whose effect of "privacy" is made possible by the thoroughly mechanized nature of its operation. But listening through headphones is still attached to relatively large pieces of machinery, which tend to remain stationary ... The form of listening that is a decisive break from the past is that made possible by the Walkman. ${ }^{18}$

By 1984, generic Walkmans were affordable and ubiquitous. The device seemed custom-made for allowing Australian listeners to retreat into their minds and pretend they were somewhere and somebody else, which at the time meant primarily living American Dreams. Australians may have had no choice but to be in Australia, but that did not mean they had to listen to its sounds. Warren's recollection of experiencing Springsteen in this way came while delivering newspapers, riding a bicycle around quiet suburban streets at dawn. West listened to Born in the U.S.A. through headphones while on a train on the way to school. Many Australians, regardless of their background, shared the same dream, listening to the album from beginning to end. To be sure, mixed cassettes, both commercial and home-made, were common, but nothing in comparison to file-sharing and the ease of compiling one's own playlists that the rise of the internet and the iPod would bring. In 1984, one could fiddle about with fast forward and reverse, but listeners were stuck with the album on tape and could

\footnotetext{
${ }^{18}$ Rey Chow, "Listening Otherwise, Music Miniaturized: A Different Type of Question About Revolution," in Doing Cultural Studies, 135-140.
}

BOSS: The Biannual Online-Journal of Springsteen Studies 1.1 (2014) 
not wholly remove themselves from the album as Springsteen - or any other artist-constructed it. That is to say, the almost simultaneous rise of the Walkman with the release of Born in the U.S.A. allowed for a relative mass displacement of Australian minds to American shores as the album was released at the peak moment of Phase One, when Australia was fascinated with all things American.

In 1986, the year following the success of "Born in the U.S.A." as a single, Australian identity became fashionable on American soil. This change was driven, for the most part, by Peter Faiman's popular film Crocodile Dundee, featuring Paul Hogan as Mick Dundee, a crocodile hunter from Australia's far north and an overblown stereotype of the easy-going, Australian outback cowboy. Dundee sits at the center of Phase Two in which Australians did not assert a character of their own but bought into the image of how they were perceived from abroad. Not only in the film itself but in Australians' widespread embrace of it, Australians were able to actively represent themselves, though this representation did not always come on their own terms. Hogan echoes this sentiment in his description of Dundee:

I made the character up that, how a lot of us think ... our image is overseas, and how the Yanks thought we were. And they thought we're this outback, pioneering, cowboy sort of, bit laid back, and charming and friendly and all that stuff. That's the character. ${ }^{19}$

\footnotetext{
${ }^{19}$ MMM Melbourne (radio station), The Hot Breakfast, Interview with Paul Hogan; broadcast November 13, 2013, accessed December 2013, http://www.triplem.com.au/melbourne/shows/hot-breakfast-eddiemcguire/video/video-paul-hogan-on-triple-ms-hot-breakfast/
}

BOSS: The Biannual Online-Journal of Springsteen Studies 1.1 (2014) 
Crocodile Dundee was a worldwide box office hit, grossing almost $\$ 48$ million in Australia in the year of its release and \$104 million in the United States, making it, at the time, the most successful foreign film ever released in the United States. ${ }^{20}$ Given the relative populations of the two countries, these figures provide a testament both to the popularity of the so-imagined Australian character in the United States as well as the willingness of Australians to embrace this imagined identity. So successful was the image of Australian identity provided by Dundee that as late as 2000 one Australian complained that Americans and others see Mick Dundee as "our bloody international mascot. We're more than Crocodile Dundee, though sometimes you'd never know it." 21

Faiman, an Australian television producer and director who had worked with Hogan previously on Hogan's variety comedy series The Paul Hogan Show, created a vehicle that would propel what we have called Phase Two onto the stage of AustralianAmerican international relations. Dundee presents a story, conceived by an Australian filmmaker, about an American journalist making a special trip to outback Australia to discover what a true Australian is like. In the end, she falls in love with him, embodying America's fascination with a romanticized version of Australianness and appropriately reflecting American audiences' zeal for Dundee. Ultimately, whether Faiman was responding to an

${ }^{20}$ David Friendly, "No Tears for 'Crocodile'," Los Angeles Times, October 2, 1986; Aljean Harmetz, "The Crossover Appeal of 'Crocodile'," New York Times, January 12, 1987, C17; Film Victoria: "Film Victoria - Australian Films at the Australian Box Office," accessed May 2014,

http://www.film.vic.gov.au/_data/assets/pdf_file/0004/967/AA4_Aust_Bo x_office_report.pdf

${ }^{21}$ Miro Cernetig, "Forget Crocodile Dundee, Aussies Plead," The Globe and Mail (Toronto, Ontario) September 14, 2000, A1.

BOSS: The Biannual Online-Journal of Springsteen Studies 1.1 (2014) 
observed cultural shift, or orchestrating what amounted to a selffulfilling prophecy, is a moot point. More important is to note that a step change was taking place as the release of Crocodile Dundee coincides roughly with the waning of Born in the U.S.A.'s time on the Australian charts. This paper stops short of suggesting that a causal relationship is apparent; more likely, Born in the U.S.A., after a run of popularity that was nothing short of astounding, had had its time, and Australians were ready for change (which included Springsteen's live box set). The success of Crocodile Dundee in both Australia and the United States constitutes an embrace of an exaggerated and romanticized encapsulation of AustralianAmerican relations, summed up in the interaction between Mick Dundee and the American reporter Sue Charlton, but this relationship between nations would mature and change with time and the rise of new technologies to facilitate interaction.

However, at the risk of further complicating this Phase One/Phase Two relationship, it is worth recalling a point made earlier with regard to the reception of the "Born in the U.S.A." single in Australia: Australians were already, to small and differing degrees, in dialogue with American culture, interpreting and interpolating themselves in light of it. That is to say, it is hard not to see elements of the archetypal American cowboy in Mick Dundee's character: cowboy hat (the string of crocodile teeth that adorn it notwithstanding); leather vest (again, clearly made from crocodile, thus holding on tight to this Australian-American interplay); not to mention the self-reliant, rugged individualism of the hero. After all, since the 1960s Australian audiences had been raised on a diet that included American Western fare such as Gunsmoke and The Lone Ranger on television as well as the films of

BOSS: The Biannual Online-Journal of Springsteen Studies 1.1 (2014) 
John Wayne in cinemas. Thus, a more nuanced interplay than we have hitherto described in this transnational communication should be noted. The two phases we have identified are not so discrete and absolute, because interactions of various kinds have long existed between Australia and America, in letters and in trade, in fleeting glimpses and glances, and occasional liaisons on a larger scale. After all, if Australians were seeking to be Americans manqué, as we have argued, then Australians' love for the United States did not take place in a vacuum. There was always already some data - a collection of stories, anecdotes, cultural artifacts upon which Australian fantasies could be built. Indeed, Born in the U.S.A. stands as a prime example of this claim. The shift between Phase One and Phase Two, then, is marked by a question of degree of interaction taking place and its different forms and uses.

If the Australian uptake of Born in the U.S.A. in 1984 was, at least in part, driven by the simultaneous ubiquity of the Walkman, this interaction ultimately proves a mere precursor of what was to come. As we have argued that a degree of technological determinism informed Phase One and, by extension, Phase Two, then the same can certainly be said of Australian-American discourse in the years that followed. In the passage from Chow cited above, she identified an "era of interiorization whose effect ... [is] 'privacy'." 22 Though Chow focused her study on the Walkman, the passage resonates strongly in an era when iPods are becoming increasingly smaller, in inverse proportion to their capacity for storing music. Thus, the process Chow describes has expanded. Similar arguments appear in the work of other cultural theorists,

22 Chow, "Listening Otherwise, Music Miniaturized," in Doing Cultural Studies, 139.

BOSS: The Biannual Online-Journal of Springsteen Studies 1.1 (2014) 
such as Paul Hopper, Abhijit Sen, and David Beer, but the phenomena to which they refer are of a different order entirely. Beer, for example, investigates the everyday use of mobile music devices. He concludes that these devices "enable the 'management,' 'reorganization,' and 'negotiation' of everyday experiences and environments. The user ... enters a 'privatized,' 'isolated,' and 'mediated' audio or sound 'bubble' that enables [him or her] to gain a sense of 'solitude' as they reclaim urban territories." 23 Yet, while such experiences may be privatized and isolated, they have also taken on a global aspect. Hopper notes that "developments in electronic media and communications technology ... may also reflect deterritorialization, providing examples of the ways in which our cultural practices, experiences, and identities are becoming separated from the places we inhabit." 24 This separation, too, was prefigured in the Australian uptake of Born in the U.S.A., but again the differences of scale today are exponential. In an age of globalization, place of national origin may have less bearing on how people perceive themselves, on who they perceive themselves to be. Other markers-occupation, hobbies, and taste in music, to name a few - may assume primacy. Through the use of contemporary technologies, a listener may have more in common with, and feel more connected to, say, an online community of fans of a particular artist or style of music than to people in immediate geographic proximity.

The firm embedding of the internet in everyday life since the mid-to-late 1990s-including YouTube, iTunes, various file-

\footnotetext{
${ }^{23}$ David Beer, "Mobile Music, Coded Objects and Everyday Spaces," Mobilities 5:4 (2010): 469, 469-484.

24 Paul Hopper, Living With Globalization. (Oxford: Berg, 2006), 44-45.
}

BOSS: The Biannual Online-Journal of Springsteen Studies 1.1 (2014) 
sharing platforms, and online shopping for music - has meant a movement beyond the first two phases of Australian-American interaction. What follows is Phase Three, insofar as what was once a mass displacement - as per the Australian experience of Born in the U.S.A. - has now become myriad singular and individual displacements, as individuals, as they wish, can choose a number of ways to engage with the American persona Springsteen represents. Given the changes in how music can be accessed, Australian listeners can more easily pick and choose their favorite songs, combine them with other songs from other places and times to create new and individualized narratives, and so create an experience of Springsteen's music that is truly their own. Sen elaborates on this process as follows:

The convergence of music production, creation, distribution, exhibition and presentation enabled by the new communications technology has swept through and shaken the music industry as never before ... Music has been the force which could cut across cultures and transcend borders ... This has happened not just at the national level but transcended borders to become a global phenomenon. ${ }^{25}$

Springsteen's more recent work has embedded within it an awareness that it will be taken and used in myriad different contexts, places, and times. This awareness has been reflected in subtle shifts occurring at the lyrical level. A comparison of "Born in the U.S.A." with a single from 2012's Wrecking Ball, "We Take Care of Our Own," seems to bear this hypothesis out. Unlike "Born in the U.S.A," with its strident and repetitive chorus all but demanding attention to the American nation, the few overt ${ }^{25}$ Abhijit Sen, "Music in the Digital Age: Musicians and Fans 'Come Together'
on the Net," Global Media Journal, 9:16 (Spring 2010), 1-25, 2-3.

BOSS: The Biannual Online-Journal of Springsteen Studies 1.1 (2014) 
references to America in the latter song (one mention each of Chicago, New Orleans, and the Superdome) occur singularly in the second verse. The pronouns "we" and "our" in the chorus remain relatively undefined, leaving scope for audiences to fill the signifiers with whomever they want "we" and "our" to be. In all fairness, there can be little doubt amongst Springsteen's fan base that "we" means Americans and when his narrator sings "wherever this flag's flown," the flag in question is the Stars and Stripes. Nonetheless, "We Take Care of Our Own," with the exception of its second stanza, does not contain the decidedly American lyrical content of "Born in the U.S.A." As it is, if different audiences want to sing along and identify differently, they can. This idea is supported in Emily Edwards's contribution to Jonathon Epstein's Adolescents and their Music: If It's Too Loud, You're Too Old: "Research ... indicates that the meaning of lyrics may be idiosyncratically created by listeners from words and phrases that are vague enough to allow listeners to construct the message from their own physical and metaphysical experience." 26 Similar ideas are also explored by Julia Kristeva in her discussion of pronouns in "The True-Real," in which she argues that "demonstratives (this, that, this one, that one) mark the passage of discourse within the system of language: they are essentially defined by the use to which they are put by the subject of enunciation ... Through the use of the many forms of enunciation which this linguistic category

\footnotetext{
26 Tim Murphey, "The When, Where, and Who of Pop Lyrics: The Listener's Prerogative" Popular Music 8:2 (May, 1989): 185-193 cited in Emily Edwards, "Does Love Really Stink? The 'Mean World' of Love and Sex in Popular Music of the 1980s," in Adolescents and Their Music: If It's Too Loud, You're Too Old ed. Jonathon S. Epstein (New York and London: Garland Publishing, 1994), 230.
}

BOSS: The Biannual Online-Journal of Springsteen Studies 1.1 (2014) 
possesses, the subject can straddle several enunciative spaces." 27 Such words are, as Toril Moi states, characterized by "their intrinsic instability and ambiguity." 28 This discussion of undefined pronouns is equally applicable in both American and Australian contexts, insofar as the flag that is flown does not need to be a national one. The song has the potential to be co-opted as an anthem for any sports team or social club, in the United States or anywhere else. The potential uptake of "We Take Care of Our Own" in Australia and elsewhere in 2014 and beyond is increased by "we" and "our own" being non-specific enough to be applied to both non-American and non-national settings.

A specific example of an Australian appropriation of "We Take Care of Our Own" proves instructive in highlighting the differences between the first single released from Wrecking Ball and the title track of Springsteen's 1984 blockbuster album. Wayne Swan, Labor Party leader and national treasurer, united his love for Springsteen's music with his political vision for Australia's future. In an August 2012 address fittingly titled "Land of Hope and Dreams," Swan spoke of his love for Springsteen's music as well as his own working-class upbringing, discussing himself and his compatriots as part of what he called the "Springsteen Generation." Swan spoke of the politics of Springsteen's music, telling his fellow citizens that Australia could learn from Springsteen, especially from his then-most recent album and, specifically, its first track: "the warning [of the album] is that if we don't include everyone and don't listen to everyone, the social discord which could follow

\footnotetext{
27 Julia Kristeva, "The True-Real," in The Kristeva Reader ed. and comp. Toril Moi (Oxford: Blackwell, 1986), 232.

${ }^{28}$ Kristeva, “The True-Real,” 216.
}

BOSS: The Biannual Online-Journal of Springsteen Studies 1.1 (2014) 
will put our growth and prosperity at risk. This is what Springsteen is speaking out against. 'Whenever [sic] this flag is flown,' he sings on Wrecking Ball, 'we take care of our own.'" 29 However, while Swan held up the inequality of the American economy as a negative model which Australians should not emulate, he did not merely use the song to compare the United States and Australia. Rather, he claimed the song's principles as an intrinsic part of a certain Australian political perspective: “We take care of our own. It's a powerful message which has enormous relevance here in Australia. It's the same egalitarian version of patriotism that gets us out of bed in the labour movement, that cuts us to the quick and stirs us into action when we see attempts to diminish it in the name of unashamed self-interest." 30 While one Australian journalist in 2014 declared "We Take Care of Our Own" one of the "unofficial American anthems of 2012," Swan read his own character and his own nation into the song. ${ }^{31}$ Unlike "Born in the U.S.A.," which, while lyrically espousing a similar set of political principles, cannot be easily applied to other national contexts, "We Take Care of Our Own," with a balder political message and vaguer set of lyrics with the exception of the second stanza-can. In 2013, Swan claimed the track from Wrecking Ball as one of his favorite Springsteen songs, one of many from which, as an Australian, he

29 Wayne Swan, "Land of Hope and Dreams," August 1, 2012, accessed July, 2014, http://australianpolitics.com/2012/08/01/land-of-hope-and-dreamsswan-button-oration.html

30 Swan, "Land of Hope and Dreams."

${ }^{31}$ Sam Kelton, "Boss Cranks Up the Heat," The Advertiser (Adelaide, South Australia), February 12, 2014.

BOSS: The Biannual Online-Journal of Springsteen Studies 1.1 (2014) 
could "get a lot of inspiration from during tough political times." 32 Noticeably absent from Swan's list is "Born in the U.S.A."

Bruce Springsteen has retained a place in the Australian cultural imagination for over four decades. The Australian appreciation of Springsteen may have altered over time, from American Dreams of the 1970s and early 1980s to more recent, increasingly nuanced engagements that allow for specifically Australian identifications with a living American music icon. These engagements, which now are largely facilitated by technologies such as the iPod, take place in a globalized space, where nations are no longer so far apart and borders are not always so important. In some ways, the reception of Springsteen's music is a case study of Australians' relationship with American music. After all, other American artists such as Michael Jackson, Lionel Richie, and Prince all topped the Australian music charts in the same year as Born in the U.S.A., and there is certainly no shortage of American fare on the Australian charts in today's globalized environment. ${ }^{33}$ However, other artists do not challenge the argument we make in this paper. Neither does their work resonate within the same space that Springsteen occupies, simply because the music they presented in 1984 was not so flagrantly tied to America or ideas of American identity as was that of the man who sang of being "born in the U.S.A.

32 Colin Brinsden, "Swan Quits as Rudd Returns," Australian Associated Press, June 26, 2013, accessed June 2014, http://www.usanews.com/article/349164/swan-quits-as-rudd-returns/

33 With Thriller, Can't Slow Down, and Purple Rain, for eleven, three, and one week(s), respectively: Kent, Australian Chart Book 1970 - 1992.

BOSS: The Biannual Online-Journal of Springsteen Studies 1.1 (2014) 